\title{
Design Principles for Lesson Study Practice: A Case Study for Developing and Refining Local Theory
}

\author{
Divan Jagals ${ }^{1 *}$, Martha Van der Walt ${ }^{1}$ \\ ${ }^{1}$ North-West University, Potchefstroom, SOUTH AFRICA
}

Received 31 January 2018 - Revised 8 May 2018 - Accepted 9 May 2018

\begin{abstract}
The practice of Lesson study in the field of mathematics education is often restricted due to the assumptions of education theory and its impact on the teaching and learning practice. The paper discusses possible constructs and design principles that arise from such preconceptions of Lesson study. By incorporating these principles into the facilitation of Lesson study, a stronger community of practice can be established. As part of an undergraduate mathematics education methodology course's content, two volunteer groups of students specialising in Grades 4 to 7 mathematics participated in the design and study of a research lesson. The aim was to determine how these students depict Lesson study in theory and practice through a-priori design principles, and how these principles led to the identifying of constructs that produced new principles that can inform the development of a (new) Local theory. The results indicate that the design principles produced constructs of metacognitive skills, metacognitive language and metacognitive networking that can be theorised. Recommendations follow on how Lesson study practice can be theorised about and facilitated through these design principles.
\end{abstract}

Keywords: mathematics education, lesson study, design-based research, design principles, metacognition

\section{INTRODUCTION, BACKGROUND AND ORIENTATION}

Lesson study is a form of professional development established first in Japan and can be used to develop a community of practice. Prospective teachers need to be prepared to, at least, manage the pedagogical challenges of their future classrooms and, as such, Lesson study is identified as one of the mechanisms that can assist in preparing students for the mathematics education profession (Cajkler, Wood, Norton, \& Pedder, 2013). Lesson study practice, therefore, offers teachers an opportunity to plan together and observe each other's lessons and then reflect on them to refine the lesson plan where needed. Lesson study is also underpinned by design principles that should be infused within its practice, including the setting of long-term goals, collegial planning of lessons, and the development of teaching and learning resources. The principles for the design of these experiences are prescriptive and provide guidelines for facilitating teaching and learning experiences in a particular context and educational milieu. The lessons offer both teachers and educationists an opportunity to reflect on and theorise about the conceptual change that may take place during the design, implementation and refinement of the lesson.

The discourse of reflective practice is embedded in a range of education programmes including undergraduate teacher education. Graham and Phelps (2003) have demonstrated the need for new programme development; especially in mathematics education such development requires the output of teachers who are able to learn to teach mathematics as specialists of both mathematics in practice, and of mathematics' teaching and learning theory. As guidelines for this professional development, some recommendations from past research exist. A report by Woodrux, Cox, Tosa, and Farrell (2013), for instance, suggests that teachers, programme administrators, policy makers and educational researchers should embed and promote reflective practice in the professional development of teachers. By implication, such reflection would kindle metacognitive skills and so teachers should become metacognitively aware of the skills they possess to think about teaching and learning mathematics. In addition, a

(C) 2018 by the authors; licensee Modestum Ltd., UK. This article is an open access article distributed under the terms and conditions of the Creative Commons Attribution License (http://creativecommons.org/licenses/by/4.0/). \12782890@nwu.ac.za (*Correspondence) $\boldsymbol{M}$ marthie.vanderwalt@nwu.ac.za 


\section{Contribution of this paper to the literature}

- The contribution of this paper to the literature lies in the attempt to offer Local theory with constructs otherwise unknown in metacognition research.

- The paper offers constructs that can produce new principles to inform the development of a (new) Local theory.

- The findings identify these constructs as metacognitive skills, metacognitive language and metacognitive networks.

case study by Chval, Pinnow, and Thomas (2015) reported that teachers need to learn how to focus on language while teaching mathematics. Recent work by Wilkerson (2017) and Baber (2017) also encourages the idea of expanding the network of mathematical capital through service-learning, whereby preservice teachers become involved in community projects where they can serve the teaching practice and learn from the experience. To acquaint teachers with the necessary professional-development skills, Mevarech and Kramarski (2014) concluded that the important role metacognition plays in such undergraduate programmes should be anticipated. The assumption is then that metacognition promotes learning, and that learning in a professional community enhances metacognition (Mevarech \& Kramarski, 2014), thereby making such learning a valuable asset in the conduct of Lesson study.

\section{Background and Context of the Study}

Place value is a topic prescribed as part of the course work of the fourth-year BEd module. It builds on one of the topics in their previous year's subject methodology course; namely, common errors and misconceptions with regard to place value. There is a scarcity of literature on the conceptual and theoretical considerations for developing theory, and facilitating Lesson study through such theory, especially in the context of mathematics education. Jagals and Van der Walt (2016) explained that theory development plays a crucial role in the understanding and development of new pedagogy; thus to develop educational theory, design principles are needed to inform the development of a theory-based learning context. The primary research question that this study then sought to answer is: What design principles emerge from Lesson study's practice, and how do these principles inform Local theory? The research reported here is founded predominantly on the preconceptions and underpinning epistemologies of Lesson study's theory and practice. Through design-based research and a qualitative approach, the partaking students' (undergraduate preservice teachers of mathematics education in Grades 4 to 7) involvement in Lesson study was interpreted by means of the design principles that emerged from their Lesson study practice.

\section{Four Stages of Lesson Study Practice within the Course}

Students who enrolled for this module received a detailed assignment schedule relating to the content of Lesson study and metacognition. Four Lesson study stages and a combination of Lesson study principles were aided in the development of Local education theory. The following four stages of Lesson study practice were implemented:

Stage 1 - Investigation: Students had to study literature on Lesson study and metacognition in mathematics education; they studied the South African mathematics curriculum on the topic of place value from Grade 1 to Grade 9; they chose Grade 4, 5, 6 or 7 to do a research lesson; they studied the context of a rural township school and they set both short-term and long-term goals. A lesson plan then had to be developed and presented through a series of design sessions. This was done locally, and the data obtained was used to improve instruction within these lesson plans. Once the lesson plan is presented, its effectiveness may be weak; it was expected that there is at least precision in the written and oral presentation of the lesson and that clear coherent arguments will reflect the style, sophistication and appropriateness of the presented lesson.

Stage 2 - Planning: The lesson plan may depend on local materials and resources and this might transform over time. During this stage is was expected that there is a clear understanding of the local needs in terms of resources and the necessary knowledge and skills to develop and design (new) resources. Students had to collaboratively plan a lesson with appropriate activities to engage students in in a series of lesson design sessions (mimicking the lesson study stages). These activities had to be relevant to students' context; they presented aspects of their planned lesson weekly to the whole group of final-year students to get peer and lecturer feedback.

Stage 3 - Research lesson: The lesson plan caters for continuous local adaptations, including innovative design changes and changes in theory. Because of its flexibility, the lesson plan is expected to undergo improvement. It was expected that the presented lesson contributes to the needs and the level of conceptualising the mathematical texts and materials. The research lesson: one of the lesson study group members presented the lesson while the rest of the group observed the lesson. The changes (or innovations) made to the lesson plan may be adapted. For example: if prior knowledge is assessed in the beginning of the lesson and it is clear that the route of the planned 
lesson cannot be followed, possible structures should be in place to accommodate anticipated processes as early as possible. Both basic and deep levels of reflection occur at this stage as the needs, resources and classroom experiences are aligned with personal beliefs, values and expectations.

Stage 4 - Reflection: The knowledge that is produced form the locally presented lesson embodies an understanding of the knowledge and skills needed locally. Students reflected on the lesson and refined the lesson plan. Observations from the classroom experiences can be reflected upon to accommodate change in needs and instructional approach in order to improve the teaching and learning experiences. It was expected that the local adaptions, improvements and diverse understandings of the product (or outcomes) of the lesson can be used to warrant its effectiveness locally. Reflections on the meaningfulness of the presented lesson are measured against a specific prescribed set of criteria or outcomes.

Based on these four lesson study stages, the following a-priori principles were considered important for the design of the courses' learning experiences. In Stage 1 long-term goals are considered for learning and development where existing curricula and policies are studied. In Stage 2 students should plan to conduct a research lesson and to collect data through reflection and observation. The data were then presented and discussed in terms of their implications. In Stage 3 the learning resources, teacher resources and teacher knowledge are strengthened to improve the effectiveness of the lesson through refinement and reflection. In Stage 4 the lesson plan reveals and promotes students' thinking whereas the resources support learning collegially. Motivation, improvement, collaboration and a sense of accountability is valued and is associated with knowledge of the subject, didactics and goals.

\section{CONCEPTUAL-THEORETICAL FRAMEWORK}

Mathematics education theory can be understood as the field in which mathematics and education theories are infused. The aim is to understand and improve the teaching and learning of mathematics in context-sensitive ways (Sriraman \& English, 2010). Lingard (2015) stressed the importance of developing mathematics education theories that filter the purposes, nature, and intent of theory to model and define relationships between the teaching, learning and doing of mathematics. In addition, it is the researchers' philosophical stance, or contextualised worldview, that contributes to the design of Local theory (Cobb, Jackson, Smith, Sorum, \& Henrick, 2013). When the focus is not to instruct students about the theory of Lesson study, but rather to explain the nature of the relationship between the constructs that emerge from its practice, then Local theory can be developed and refined.

\section{Metacognitive Skills}

Metacognition is commonly defined as "thinking about thinking" (Flavell, 1979, p. 908). Studies by Mavarech and Kramarski (2014) revealed that teachers, and mathematics teachers in particular, seldom effectively actuate their thinking processes. They show an inability (or unawareness) to plan, monitor and evaluate their own and their students' comprehension successfully. Teachers who do show initiative in applying their metacognitive skills show this usually during lesson planning as they outline the activities that will follow, and during lessons they are likely to adapt their instruction as needed. However, a consequence of a lack of the expression of one's thinking can hinder the students' exposure to metacognitive-oriented teachers who model the act of assessing one's thinking and understanding and follow-up with an opportunity for their students to implement metacognitive skills themselves.

When examining and investigating metacognitive skills, a vital undertaking is being mindful of students' expertise in monitoring, thinking about and managing their own particular intellectual procedures of learning (Schoenfeld, 2016). Metacognition follows up on the perceptions and manages the ideas based on reflection. Metacognition can, in this manner, be seen as a person's own support of information and administration of one's reasoning. Metacognitive skills therefore allude to comprehension and controlling information (Schraw \& Moshman, 1995). However, a particular kind of language and networking is needed in Lesson study as Jagals and Van der Walt (2016) showed in the case of narrative focus-group interviews. Reference is therefore made, in this regard, to language and networking in a more transformative and metacognitive fashion, a refined way in which the Lesson study participant becomes aware of their language of thinking and expressing of their thoughts, and the networks (interpersonal, social and socially regulated) that they exhibit when doing so. These kinds of expressions are referred to as metacognitive language and metacognitive networks.

\section{Metacognitive Language}

A language is needed to express ideas. Farrell (2015) claimed that the absence of understanding one's thinking is the result of no language of thinking being involved, and so no communication about the ideas in one's mind can exist between the metacognitive knowledge and regulatory domains. Such a language of the mind can be expressed 
through the term metacognitive language, and represents the particular language used when reflecting on experiences or experiences of thinking. Ducasse, Denker, and Lienhard (2009) proposed the notion of exhibiting your reflections, for example, expressing your thinking verbally (spoken language) or non-verbally (through art, mystic and gestures). Such a language has different functions in mathematics education; Nachlieli and Tabach (2012) demonstrated three types of discourses in mathematics education, discussed next.

Ideational and mathematical language refers to the ideas that emerge as students discuss mathematical concepts and the use of appropriate strategies. This often involves algebraic symbols or expressions, graphs or tables in realworld problems. This language builds on ideas (as in constructivism) and is observed to have a gradual increase in the level of difficulty as more complex mathematical ideas emerge from discussions. This serves as an imperative description of mathematical ideas. Interpersonal and social language refers to informal and formal use of words, indicating ownership or sharing of ideas. These ideas can refer to various scenarios where the individual asks for assistance, explains their own thinking or translates or rephrases an idea for someone else. Textual and pedagogical language includes the terms or words used which relate to one another. For instance, a teacher can acknowledge a learner's choice of use of visual or symbolic representations. The pedagogical aspect implies forged linguistics between the tasks and strategies that refer directly to education as a task of teaching and learning. Textual and pedagogical language serve as functions of discourse in mathematics education (Nachelieli \& Tabach, 2012). For a deeper elaboration on these discourses the reader can refer to Jagals (2015).

It appears that metacognitive language is closely coupled with a networking nature (considering the social attributes linked to it). In doing so, the expression of one's thinking through a metacognitive language hints of the hidden role of the networks that emerge through this language.

\section{Metacognitive Networking}

Theories of networking usually include the characteristics that arise from thinking. A network as a set of actors (or capacities such as skills and thoughts) that are linked due to a type of relationship that exists between them (i.e. cognitive, social and affective relationships). The actors could exist as nodes joined through links. In terms of metacognition, network aspects can be informative about the nature of teaching and learning when individuals collaborate during a group task (such as Lesson study). Examples of such a meta-language include: I think ... I know ... I feel ... The particular roles that individuals portray in these networks of thinking, knowing and feeling, as well as the thinking and reflecting processes, can be portrayed as metacognitive networks, as Jagals and van der Walt (2016) showed in their analysis of metacognitive networks. Pasquali, Timmermans, and Cleeremans (2010) conveyed this thinking about networks in terms of networks' metacognitive nature as such networks can help answer the question: What is the cognitive nature of the relationship of this thinking? Such networks imply that individuals in a group setting take on certain roles (in terms of social network analysis, e.g. a coordinator, a socially weak member, a gate keeper). They can also portray specific individual metacognitive networks that are interpersonal in nature, such as reflecting on one's own thinking (see Jagals, 2015, p. 165-169 for detailed portrayals of these networks), and networks that represent socially shared metacognition, as in the case of theory of mind (Papaleontiou-Louca, 2008). There are three types of metacognitive networks that exhibit the levels of the locale of metacognition. These include networks on a social level as a social network, networks on an interpersonal level and networks on a socially shared level. The social network portrays the different social roles and the dynamics between participants in this network. The interpersonal metacognitive networks reflect the unique metacognitive characteristics that all members of the social network hold (e.g. being a compulsive planner, a mediator of knowledge within the group). The socially shared metacognitive network shows how ideas are collaborated and shared, how one individual plans for and with another. This third metacognitive network type represents the metacognition shared by two people involved in the same activity.

\section{Underlying Assumptions of Lesson Study}

Craddock, O'Halloran, McPherson, Hean, and Hammich (2013) proposed that teachers' professional development and the reinforcement of teaching and learning practice strengthens the value of theory by highlighting its implications in educational practice. While education theory influences teaching practice, it also reveals knowledge about teaching and learning experiences, and puts forward alternative practices and ideas that result from these experiences (Bernath \& Vidal, 2007). This pragmatic view on the development of effective teaching and learning experiences relates to the Japanese model of adapted Lesson study. To apply, understand and explain constructs as components of the knowledge that emerge from and result in theory, Bernath and Vidal (2007) argued that such theories shift from traditional educational pedagogy towards practically relevant educational theory. Lesson study can then be facilitated by aligning its principles in practice and revisiting them with theory. Nickerson and Whitacre (2010) claimed that the knowledge and skills of conducting Lesson study include planning, analysing, testing out, reflecting on and refinement of lessons. 
In doing so, the value of Lesson study in mathematics education seems indispensable. In support of this, Cobb et al. (2013) suggested that pedagogies should be re-examined to bring theory and practice together, and to develop and refine theory. Furthermore, to conduct Lesson study requires deep reflection as a metacognitive skill when planning, monitoring and evaluating the effectiveness of the lesson. Flavell (1979) defined this reflection as metacognitive skill (also see Frith, 2012). Likewise, individuals can find it challenging to express their thinking about these metacognitive skills if they have to explain their reasoning to other members of the Lesson study group. During such collaboration on the design and refinement of lessons, group members (usually between five and eight) plan together, observe and reflect on each other's inputs and learn to work collegially in a network. Theory development to facilitate Lesson study therefore includes these skills to hypothesise about the route to follow and what learning trajectory to plan for. Stemming from these two assumptions, design principles can be developed to facilitate Lesson study in undergraduate teacher-preparation programmes.

\section{Concepts Underpinning Lesson Study}

Lesson study originated in Japan as an inquiry model for developing professionalism of teachers. Referring to the adapted Japanese Lesson study model implies that in other contexts, such as a South African mathematics education course, the Lesson study model can be adapted to suit the particular needs of the setting or milieu (or content) in which the Lesson study practice takes place. Participants involved in the Lesson study process typically exhibit collaborative, planned, reflective and observational qualities during the stages of Lesson study. These qualities also underlie the particular constructs identified in the introduction of this paper, including: metacognitive skills (Flavell, 1979); language (Chval et al., 2015); and networking (Baber, 2017; Wilkerson, 2017).

\section{THE RELATIONSHIP BETWEEN DESIGN PRINCIPLES AND LOCAL THEORY}

The unique makeup of the metacognitive nature of skills, language and networks has allowed theory to evolve in complexity. The theory of metacognitive locale by Jagals (2015) is but one example where Local theory was developed based on the metacognitive characteristics of language and networks that emerge during a series of Lesson study stages. The relationship between a particular kind of language and a particular kind of network produces a kind of reflective experience, and this informs the principles needed to design Lesson study practice. These design principles on which the Lesson study stages are based exist a-priori in the literature. These principles include the setting of long-term goals, studying existing curricula and policies, reflecting on existing data and observations, discussing implications, strengthening resources, scrutinising the role of the lesson plan in terms of developing students' thinking, and including motivation as a valuable sense of accountability. Therefore, Local theory does not appear to exist alone; instead, the principles underpinning Lesson study's practice support and explain the instructional activities as well as outline the implications of the activities in practice. The connection, then, between the design principles and the Local theory is a complex one, discussed next.

When Lesson study stages are followed, hypothetical constructs can emerge which act as archetypes of the design principles on which these stages are based. For example, Jagals and Van der Walt (2016) showed that constructs of metacognitive networks emerged during a series of lesson-design stages whereby preservice teachers were involved in conducting Lesson study. These principles do not appear to be consecutive; in other words, they do not seem to emerge as a consequence of another principle, or emerge in any particular order. Examples of such constructs can include (but are not limited to) metacognitive skills, metacognitive language and metacognitive networks, as identified for the purpose of this paper. Throughout Lesson study's stages, the sessions during which lessons are planned together can serve as design sessions. It is therefore possible that a lesson study stage can consist of a number of design sessions. The design principles on which this practice is based can serve as guidelines and structures, sometimes predetermined, or as part of a conjectured process. This series of stages and sessions with the incorporated design principles can assist in facilitating Lesson study meaningfully, and this can inform the development and refinement of theory. This is done on four conditions.

First, the theory that needs to be developed requires deep reflection on the constructs that emerge from Lesson study's practice as they support and explain the design principles that can be used to test and refine the theory (Cobb et al., 2013). Second, by implementing the design principles, new knowledge can emerge that supports the impact of the principles on how the constructs are interpreted. This can result in a localised or contextualised explanation of the design principles' structure and function in Lesson study. Third, a meta-theory can act as a standard theory to refine the design principles and inform the development of Local theory. The meta-theory mainly focuses on the effect(s) of the teaching practice and does not only explain the relationship between the constructs that emerge but also support the purpose of both guidelines produced and the Local theory. Lastly, the constructs that emerge from implementing the design principles can be predetermined, making them purposively conveyed in the design of the Local theory. This predetermined, hypothetical conjecture can be implemented by following the theory's guidelines. 
Local theory, therefore, predicts and explains the nature of the constructs which do not necessarily have to form part of the steps or guidelines of design principles. Rather, Local theory regards the constructs as the result or output of the design principles. Similarly, Cobb et al. (2013) and Gravemeijer (2004) have reported on the input and output variables in the development of design principles as part of Local theory's development. These design principles can then be reflected upon and refined to provide more informed or alternative principles. The design principles can then inform the facilitation of Lesson study. To do so, two options are available. The first option suggests that the design principles obtained a-priori from literature inform the facilitation of the Lesson study stages as indicated by Larsen and Lockwood (2013). The second option indicates that the Local theory can also inform the design principles as is the case with a study done by Nickerson and Whitacre (2010). Within a larger project, this can be done with a design-based research identity (such as the case with Jagals, 2015). The Lesson study stages therefore indicate continuous design sessions (or even micro stages) that produce recurring or comparable results (in the form of design principles and/or constructs) and enable the teacher as a researcher to formulate, test and refine the conjectured design principles. The teacher can therefore act as a researcher-facilitator who makes use of Lesson study as a teaching experiment. Cobb et al. (2013) and Gravemeijer (2004) explained that the role of the teaching experiment is to test and improve the design principles. The design of these teaching experiments forms the basis of a planned Lesson study stages (Bustang, Zulkardi, Darmawijoyo, Dolk, \& van Eerde, 2013) that could inform the way in which Lesson study is facilitated in the classroom as part of a mathematics education course's content. The following methodology was thus employed.

\section{METHODOLOGY}

In order to identify and develop the design principles to facilitate Lesson study, a design-based research methodology was applied with a qualitative approach. The aim was to interpretively explore the constructs that emerge from implementing Lesson study's stages and to derive design principles from these constructs to inform the development and refinement of a Local theory. Based on the conceptual-theoretical framework of this study, it is believed that these principles can inform the development of Local theory through an understanding of nature of the relationship between them.

\section{Population and Sampling}

The study began by inviting two volunteer groups (Group A and Group B) of fourth-year mathematics education students enrolled for a course on the methodology of Grades 4 to 7 mathematics. As part of their coursework, students had to plan and design a mathematics lesson on the topic of Place value (with an emphasis on didactics) and present it to a Grade 6 class at a nearby primary school in a township area as part of Lesson study's stages. The participants represented both male and female students from various ethnic backgrounds and their home language is Afrikaans, English and/or Setswana. They have also observed, planned and presented mathematics lessons in similar schools during the work-integrated learning opportunities the urban campus offered through its Bachelor of Education (BEd) programme. In Group A there were six students represented by one male and five females while in Group B there were five students represented by one male and four females. The participants were encouraged to think aloud and share ideas during design sessions across the four Lesson study stages, similar to a focus-group context.

\section{Data Collection}

The aim of the design sessions was to create an opportunity for participants to engage in the Lesson study stages. Data include transcriptions of video recordings of all the design-group sessions. A framework to outline the design sessions was borrowed from the work of Cobb et al. (2013) and include four design-based research stages, mimicking the Lesson study stages: 1) investigate problems and set goals; 2) plan the lesson and resources; 3) research the lesson's effectiveness; and 4) reflect and refine the lesson. Lesson study was facilitated at the university where participants were enrolled and, on completion of the first draft of the research lesson, a volunteer from each group was asked to video-record and present the lesson while other members of the group observe and reflect in order to generate notes and recommendations for refinement. This also added validity and trustworthiness to the data as it resembles multiple perspectives on the same phenomenon.

\section{Data Analysis}

The sessions' transcriptions were analysed through conversation analysis to describe, summarise and explain the constructs, to identify and refine the design principles, and to inform the development of Local theory. To do so, the verbatim-transcribed recordings were analysed and coded using the codes-to-theory model for qualitative 
Table 1. Application of the codes-to-theory model

\begin{tabular}{|c|c|c|c|}
\hline Code & Category & Sub-category & Description of the sub-category to inform the design principles \\
\hline \multirow{3}{*}{ MCS } & \multirow{3}{*}{$\begin{array}{l}\text { Metacognitive } \\
\text { skills }\end{array}$} & Planning & $\begin{array}{l}\text { Setting goals, selecting appropriate strategies, predicting the outcome of an event, } \\
\text { organising strategies }\end{array}$ \\
\hline & & Monitoring & $\begin{array}{l}\text { Recalling and reflecting to judge consciously the ideas, actions and contributions of } \\
\text { oneself and others }\end{array}$ \\
\hline & & Evaluation & $\begin{array}{l}\text { Appraisal of the efforts, processes and products of the planned experiences and the } \\
\text { revision of goals }\end{array}$ \\
\hline \multirow{3}{*}{$\mathrm{MCL}$} & \multirow{3}{*}{$\begin{array}{l}\text { Metacognitive } \\
\text { language }\end{array}$} & $\begin{array}{l}\text { Ideational and } \\
\text { mathematical }\end{array}$ & $\begin{array}{l}\text { Ideas emerge as students discuss mathematical concepts and the use of appropriate } \\
\text { strategies, awareness of the strategies and gradual increase in the level of difficulty }\end{array}$ \\
\hline & & $\begin{array}{l}\text { Interpersonal } \\
\text { and social }\end{array}$ & $\begin{array}{l}\text { Informal and formal use of words, the sharing of ideas, reference to scenarios, translating } \\
\text { or explaining for oneself and/or others }\end{array}$ \\
\hline & & $\begin{array}{l}\text { Textual and } \\
\text { pedagogical }\end{array}$ & $\begin{array}{l}\text { The use of terms or words in relation to one another, forged linguistic ties between tasks } \\
\text { and strategies; new information creates opportunities for chance in the description and } \\
\text { understanding }\end{array}$ \\
\hline \multirow{3}{*}{$\mathrm{MCN}$} & \multirow{3}{*}{$\begin{array}{l}\text { Metacognitive } \\
\text { network }\end{array}$} & Social network & $\begin{array}{l}\text { A social network based on the dynamics and interaction of members of the group (they } \\
\text { act as a liaison, a bridge or gatekeeper, an investigator) }\end{array}$ \\
\hline & & $\begin{array}{l}\text { Interpersonal } \\
\text { metacognitive } \\
\text { networks }\end{array}$ & $\begin{array}{l}\text { These networks reveal what metacognitive skills (e.g. planning, monitoring or evaluating) } \\
\text { members exhibit individually }\end{array}$ \\
\hline & & $\begin{array}{l}\text { Socially shared } \\
\text { metacognitive } \\
\text { network }\end{array}$ & $\begin{array}{l}\text { These networks reveal what metacognitive skills (e.g. planning, monitoring or evaluating) } \\
\text { members exhibit during their interaction in group discussion of the Lesson study stages }\end{array}$ \\
\hline
\end{tabular}

enquiry by Saldana (2015). The process involved coding the transcriptions, categorising them and aligning them with the constructs of metacognitive skills, metacognitive language and metacognitive networking as Table 1.

It is important to note that, for development of the Local theory, the three emerging constructs inform, through their sub-categories, the design principles that need to be considered in the facilitation of Lesson study. Examples of statements for each category and sub-category are offered in Table $\mathbf{2}$ in the results section of this paper.

\section{TRUSTWORTHINESS AND VALIDITY}

Through inter-coder reliability (with a reliability coefficient of 0.9 ) we refer to the extent to which the same codes were assigned to transcribed text by different coders. The authors collaborated on the consistency of the codes and the ideas that were coded to ensure that the findings presented reflect this consistency. Also, the guidelines by Elliott, Fischer, and Rennie (1999) were followed, including: participant checking and comparing the results with the conceptual-theoretical framework of the study. Furthermore, there was a thick description of the empirical investigation and findings, employing within-method triangulation where transcriptions of the design sessions, field notes and observations served as different methods within the same methodological approach (Curtin \& Fossey, 2007).

\section{RESULTS AND FINDINGS}

The Lesson stages allowed us to explore the constructs that emerged as a result of the a-priori design principles. The constructs were identified as: metacognitive skills, metacognitive language and metacognitive networks. Underpinning these constructs are students' expectations, understandings of one another, available time and working together in determining their success in Lesson study. These constructs, therefore, inform the way in which students became aware of the role that the constructs play across the stages of Lesson study, and in so doing, informed the design principles that need to be taken into consideration when facilitating Lesson study in the future.

In each of the themes that follow, a summary of the actual pattern of codes that the data revealed is depicted to provide a profile of the themes. Each profile contains the frequency $(\mathrm{Hz})$ of responses for the particular subcategories that emerged. Note that the frequencies serve as indicators of the quotes from transcriptions that represent the sub-category completely. It is possible that more responses could have been counted as they could imply or hint upon a sub-category, yet these were believed to have been too implicit for identifying design principles.

Table 2 provides a summary of the profiles for each sub-category and theme with examples across the four Lesson study stages. 
Table 2. Summary of the profiles of the themes and sub-categories with examples

\begin{tabular}{|c|c|c|c|c|c|c|c|c|c|}
\hline Theme & Sub-category & $\begin{array}{l}\text { Stage } 1 \\
\text { (Investigation) }\end{array}$ & $\mathrm{Hz}^{*}$ & $\begin{array}{l}\text { Stage } 2 \\
\text { (Planning) }\end{array}$ & $\mathrm{Hz}$ & $\begin{array}{l}\text { Stage } 3 \\
\text { (Research lesson) }\end{array}$ & $\mathrm{Hz}$ & $\begin{array}{l}\text { Stage } 4 \\
\text { (Reflection) }\end{array}$ & $\mathrm{Hz}$ \\
\hline \multirow{3}{*}{ 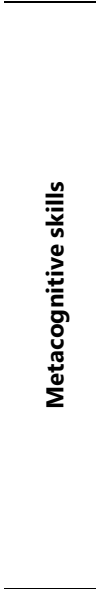 } & Planning & $\begin{array}{l}\text { I think we must first start } \\
\text { with the outcomes because } \\
\text { the outcome is going to be } \\
\text { our basic guideline } \\
\text { [Student 1] }\end{array}$ & 7 & $\begin{array}{l}\text { write what we are going } \\
\text { to do in the } \\
\text { introduction, what we } \\
\text { are going to teach and } \\
\text { learn and what we are } \\
\text { going to do at the end } \\
\text { and the activities also } \\
\text { [Student 2] }\end{array}$ & 8 & $\begin{array}{l}\text { The school } \\
\text { environment was a } \\
\text { lot better than I } \\
\text { thought [Student 9] }\end{array}$ & 3 & $\begin{array}{l}\text { We had too many } \\
\text { activities [Student 2] }\end{array}$ & 4 \\
\hline & Monitoring & $\begin{array}{l}\text { I think not at all, since } \\
\text { what we learn here and } \\
\text { what they are doing there } \\
\text { is entirely different } \\
\text { [Student 1] }\end{array}$ & 8 & $\begin{array}{l}\text { I agree, but we shouldn't } \\
\text { focus too much on } \\
\text { making it interesting, } \\
\text { we should stick with the } \\
\text { columns [Student 2] }\end{array}$ & 5 & $\begin{array}{l}\text { They were pretty } \\
\text { good. You could see } \\
\text { in their faces that } \\
\text { they understand } \\
\text { [Student 9] }\end{array}$ & 4 & $\begin{array}{l}\text {... we said that there was } \\
\text { a problem, that not all } \\
\text { kids can read English } \\
\text { [Student 2] }\end{array}$ & 8 \\
\hline & Evaluation & $\begin{array}{l}\text { Even if they don't get } \\
\text { around to it, they can still } \\
\text { tell the teacher ... and she } \\
\text { can still use the idea. It's a } \\
\text { good idea [Student 3] }\end{array}$ & 6 & $\begin{array}{l}\text { I don't think this is part } \\
\text { of their prior knowledge, } \\
\text { but I like the idea, I } \\
\text { think it is going to work } \\
\text { [Student 5] }\end{array}$ & 2 & $\begin{array}{l}\text { We also say the big } \\
\text { block and the small } \\
\text { blocks...but then } \\
\text { volume comes in } \\
\text { again [Student 4] }\end{array}$ & 5 & $\begin{array}{l}\text { I think our lesson worked. } \\
\text { I think it worked very well } \\
\text { [Student 2] }\end{array}$ & \\
\hline \multirow{3}{*}{ 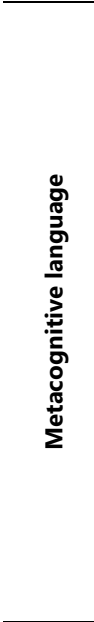 } & $\begin{array}{l}\text { Ideational and } \\
\text { mathematical }\end{array}$ & $\begin{array}{l}\text { I was thinking: I can make } \\
\text { a place value chart } \\
\text { [Student 6] } \\
\text { Lets see what the CAPS } \\
\text { document says [Student 7] }\end{array}$ & 7 & $\begin{array}{l}\text { Can we not ask them } \\
\text { like a question to make } \\
\text { them think about place } \\
\text { values? [Student 2] }\end{array}$ & 5 & $\begin{array}{l}\text { Let's see, what is } \\
\text { the difference } \\
\text { between this block } \\
\text { and this smaller } \\
\text { block? [Student 6] }\end{array}$ & 6 & $\begin{array}{l}\text { They got a worksheet } \\
\text { with base ten blocks but } \\
\text { they didn't know what } \\
\text { base } 10 \text { blocks are or } \\
\text { how to use it to represent } \\
\text { place values [Student 5] }\end{array}$ & 3 \\
\hline & $\begin{array}{l}\text { Interpersonal } \\
\text { and social }\end{array}$ & $\begin{array}{l}\text { From now on we will be } \\
\text { straight forward with each } \\
\text { other [Student 3] }\end{array}$ & 3 & $\begin{array}{l}\text { We said that we will test } \\
\text { their prior knowledge, } \\
\text { but how are we going to } \\
\text { test their prior } \\
\text { knowledge? [Student 2] }\end{array}$ & 4 & $\begin{array}{l}\text { We can be } \\
\text { assistants. The } \\
\text { assistant goes and } \\
\text { help to quickly see } \\
\text { of the kids } \\
\text { understand. Then } \\
\text { we can discuss it. } \\
\text { [Student 2] }\end{array}$ & 5 & $\begin{array}{l}\text { I think it went well. The } \\
\text { time was limited and we } \\
\text { could see the kids picked } \\
\text { up on that [Student 10] }\end{array}$ & 4 \\
\hline & $\begin{array}{l}\text { Textual and } \\
\text { pedagogical }\end{array}$ & $\begin{array}{l}\text { If we have to plan a lesson, } \\
\text { we would know how to } \\
\text { carry on because we know } \\
\text { exactly what to do } \\
\text { [Student 4] }\end{array}$ & 10 & $\begin{array}{l}\text { We have to look at what } \\
\text { level they are on } \\
\text { [Student 5] }\end{array}$ & 2 & $\begin{array}{l}\text { If you write it like } \\
\text { this: four times ten } \\
\text { plus eight times } \\
\text { one, it's correct } \\
\text { [Student 4] }\end{array}$ & 8 & $\begin{array}{l}\text { We were unsure what to } \\
\text { do, but saw what we did } \\
\text { worked [Student 6] }\end{array}$ & 4 \\
\hline \multirow{3}{*}{ 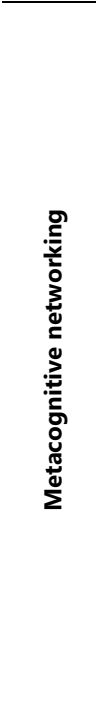 } & Interpersonal & $\begin{array}{l}\text { I compiled a lesson plan } \\
\text { template and I completed } \\
\text { my own form [Student 1] }\end{array}$ & 11 & $\begin{array}{l}\text { I think we must start } \\
\text { with the outcome, } \\
\text { because the outcome } \\
\text { will be our guide } \\
\text { [Student 1] }\end{array}$ & 4 & $\begin{array}{l}\text { I will outline the } \\
\text { words here, if } \\
\text { someone wants to } \\
\text { add anything, they } \\
\text { can [Student 11] }\end{array}$ & 5 & $\begin{array}{l}\text { I really struggled ... } \\
\text { [Student 10] }\end{array}$ & 8 \\
\hline & Social & $\begin{array}{l}\text { So, we have decided in the } \\
\text { first lesson we are not } \\
\text { going to talk about } \\
\text { fractions [Student 10] }\end{array}$ & 15 & $\begin{array}{l}\text { What are we going to } \\
\text { do in the introduction? } \\
\text { What will they learn? } \\
\text { What activities can we } \\
\text { use? [Student 2] }\end{array}$ & 7 & $\begin{array}{l}\text { We can move away } \\
\text { from what they } \\
\text { understand to what } \\
\text { they can apply } \\
\text { [Student 5] }\end{array}$ & 5 & $\begin{array}{l}\text { There are many ideas } \\
\text { which we can do better } \\
\text { [Student 8] }\end{array}$ & 7 \\
\hline & Socially shared & $\begin{array}{l}\text { Do you get what I am } \\
\text { saying? [Student 3] } \\
\text { Did you understand what I } \\
\text { mean? [Student 6] }\end{array}$ & 6 & $\begin{array}{l}\text { We have to take } \\
\text { everybody's ideas into } \\
\text { consideration [Student } \\
8 \text { ] }\end{array}$ & 5 & $\begin{array}{l}\text { We realised what } \\
\text { we did not know } \\
\text { [Student 4] } \\
\text { We had a lot of } \\
\text { ideas and could not } \\
\text { easily reach } \\
\text { consensus. There } \\
\text { were always } \\
\text { problems with the } \\
\text { ideas we had. But } \\
\text { then we worked on } \\
\text { that [Student 8] }\end{array}$ & 6 & $\begin{array}{l}\text { As a group we have come } \\
\text { together and did research } \\
\text { about a specific subject, } \\
\text { to expand our knowledge } \\
\text { so that we can develop } \\
\text { an effective lesson } \\
\text { [Student 10] }\end{array}$ & 5 \\
\hline
\end{tabular}

* This column represents the number of times the sub-category was located within the data per Lesson study stage and serves as the frequency of the coded data. 


\section{METACOGNITIVE SKILLS AS A DESIGN PRINCIPLE}

For the theme metacognitive skills, participants from both groups showed growth in their depictions of Lesson study and its value for practice as they learned to think about their thinking and to manage their ideas, a metacognitive conduct. At first, they were unaware of knowing how to plan and set realistic goals for Lesson study. They had diverse ideas that were "scattered" as they were unsure about what activities to include in their lesson and how to choose which ideas are more suitable.

The profiles of the data summarised in Table 2 suggest that participants who plan, monitor and evaluate their contributions to the design sessions do so mainly by monitoring and evaluating the other member's ideas. In particular, it seems that those who contributed to the least overall with the skill of planning exhibited more monitoring and evaluating skills. In stage 2, it seemed that participants did not know what to focus on, when to focus on the content and when to focus on the methodology of the lesson. Reflecting on how they felt/ what they experienced when they had initially engaged with Lesson study team members, there was a sense of uncertainty, particularly during Stage 2:

I would say that we were not sure what to expect... We have to start all over ... We felt that our ideas were not important as some ideas will work and others' not ... Now we are much more confident ...

In terms of the skill of monitoring (reflecting on what had happened during their lesson presentation), they related the theory of Lesson study with its practice and communicating about it, as is evident from Stage 3:

There are many ideas which we can do better ... it was very insightful ... we looked at how the learners did the work ... they all seem to understand the work, but they made the same small errors ... If we had to do it again, we will be better prepared...

The skill of evaluating was predominantly applied when participants reflected on the design of the lesson and on its presentation, thus reflecting on the teaching and learning experience. They evaluated the intelligence of the learners whom they taught: They were very smart, as well as the overall impact of the lesson: Yes, I think our lesson worked. I think it worked very well.

During the second and third stage, they divided the work amongst themselves and arranged additional sessions. They worked together, collaborated and made decisions about their ideas, specifying what to include and exclude in the lesson.

\section{METACOGNITIVE LANGUAGE AS A DESIGN PRINCIPLE}

Across all stages, not being able to express their reasoning clearly, and lacking the vocabulary of their thinking about their thinking, participants explained that, even though they worked together, they often became frustrated when their ideas are not understood or recognised.

It seems as if the interpersonal and social language was the least exhibited when ideational and mathematical language was used to express ideas. It implies that participants' mathematics vocabulary did not feature when they discussed the lesson plan, teaching activities or other pedagogical related matters of the lesson (Stage 1). Those who did use ideational and mathematical language expressed less concern about the text of the lesson plan and used less pedagogical language (Stage 2) related to teaching strategies and activities. It seemed overall that participants had difficulty with externalising their ideas as was evident from their discussion in Stage 3:

We talk past each other and do not understand what the other one means. ... we do not understand what each other means. I don't know what they don't know and what someone else is thinking about my idea ... we had too many good activities and we do not know how to say that we do not want to use this or that idea...

Participants also seem to have grown their awareness of language as was reflected on in Stage 4:

We now know each other and we can say this or that won't work. At first, we were afraid of what someone else might say ... we didn't want to demotivate anyone ... and felt that we need some way of saying what we think...

In order to get focus, participants discussed what their lesson outcomes should be; this presented a problem, not only for interpreting the curriculum documents, but also to put clearly down in words on the lesson plan what they expect from their learners at the end the lesson: 
We have outcomes, we want them to be able to identify and apply... The outcomes must be smart. It must be specific, measurable, attainable, relevant and traceable ... so we have to look at it again ...

\section{METACOGNITIVE NETWORKS AS A DESIGN PRINCIPLE}

The nature of networking between group members also developed along with their metacognitive skills and language. In stage 3, participants decided to work with each other's ideas, and not necessarily to come up with new ones all the time. In stage 3, participants had realised what their strengths and weaknesses were, and the nature of their metacognitive networking is likely to be the key to overcome the barriers participants had during Lesson study.

We are all here, we know what to do. We have to take everyone's ideas into consideration ... (Stage 2)

Discussions seemed to have flowed in a rather linear manner. First participants discussed and shared ideas in a rather socially open way:

We started with an idea and talked about it and made a combination of all the ideas. (Stage 3)

Then they reflected on these inputs on an interpersonal level:

It helped to understand the concept better... Lesson study is difficult if one student feels separated from another... (Stage 3)

They finally socially shared and regulated each other's ideas and their preconceptions of Lesson study:

When we get together we can say, this stuff works great and then we take other ideas and we build on that. (Stage 3)

Overall, the results indicate that participants communicated their ideas about teaching (e.g. teaching strategies and resources) more easily than their ideas about mathematics. It seemed that the role of a social responsive community of practice has led to the development of a mid-way in stage 3, through which they became more focused, more relaxed with their ideas and more open to new judgements and new ideas.

In this sense, metacognitive skills, metacognitive language and metacognitive networking appear to form a conceptual framework of students' depictions of Lesson study. When aligned against the design principles, the constructs offer a view on some preconceptions on Lesson study to refine the design principles and to inform the development of Local theory. The discussion that follows illustrates this in two parts. First, the emerging results are discussed in terms of the constructs metacognitive skills, metacognitive language and metacognitive networks as themes in which the design principles are attributed. Second, the implications of the design principles on Local theory development are discussed to show how these principles inform Local theory.

\section{DISCUSSION}

To facilitate Lesson study, design principles were developed and tested out (see Table 1) in the form of four Lesson study stages. From these design principles, three constructs emerged from students' depictions of Lesson study, namely metacognitive skills, metacognitive language and metacognitive networking. By aligning the constructs with the design principles and following three preconceptions of Lesson study were derived to refine the design principles and inform Local theory. Students' depictions suggest that it is possible that the design principles of Lesson study can foster metacognitive skills, promote awareness of students' metacognitive language to collaborate and create opportunities for metacognitive networking. The following preconceptions outline this discussion.

\section{EMERGING CONSTRUCTS AS DEPICTIONS OF DESIGN PRINCIPLES}

First, to develop design principles of Lesson study, the assumptions that underpin Lesson study must be considered. Clarity was needed as to what outcomes of Lesson study will be assessed and/or anticipated in a finalyear mathematics education methodology module. It is possible that similar studies can produce different constructs, depending on the local issues of the theory. In this case, we proposed that facilitators of Lesson study must first consider what underpinning knowledge, skills and values they want their students or colleagues to demonstrate and this must be in line with the design principles of Lesson study. Furthermore, the use of a task, such as lesson planning, and the opportunity to carry out this task in a series of manageable sessions, made it possible to observe for emerging constructs. 
Since metacognitive skills are an important aspect of Lesson study, it could be expected that students will plan, monitor and evaluate their lessons. In the stages below, examples are provided of some of the implications that the emerged constructs have in terms of the design principles for Lesson study practice.

Metacognitive skills appeared to be the product of social interaction. Iiskala, Vole, Lehtinen, and Vauras (2015) introduced the concept of socially shared metacognitive regulation through a social network analysis approach. This explains why students who participate in group discussions in Lesson study's design stages monitored and evaluate other's ideas and became metacognitively aware of the required language and networking qualities they exhibited and experienced. When reflecting on the research lessons, they judged whether the contributed knowledge was part of their planning and pedagogical content knowledge.

The results show that students also planned their time for additional sessions, discussed whether the outcomes are clear enough and reflected on their own experiences. When aligned with the design principles, the construct of metacognitive language did not fit with the overall framework, suggesting that communication ought to be promoted in the facilitation session. This will likely infuse a stronger sense of being in the groups.

Since participants felt cautious about their contribution to the group, another conceptual point to consider is finding ways to develop participation. This relates closely to the networking construct that, in a way, depends on the metacognitive skills and metacognitive language as also can be shared, observed and developed over time (Cajkler et al., 2013). In addition, a stronger capacity to express one's thoughts, to reason and to redefine meaning in the design sessions, was needed and can undermine participation. However, being immersed in a group long enough can imprint a sense of group culture where the group members develop a deeper understanding of their own, and others' contributions.

\section{ALIGNING THE CONSTRUCTS WITH DESIGN PRINCIPLES ACROSS LESSON STUDY STAGES}

When aligned with Table 1, the constructs serve a dual purpose. They indicate possible outputs of the theory and, serve as an input of the theory. At this point, overlaps between the constructs can unfold suggesting that, for example, metacognitive skills can be communicated about, associating it with language. Also, an expression of one's thinking can impact on the nature of others' understanding (Frith, 2012) and is associated with networking. The results point out that the preconceptions are epistemological in nature as they align with the design principles on which Lesson study was based. Participants recalled not only what they think worked in Lesson study, but also what they think could have been planned and implemented differently. The theory is then connected via a metatheory that underpins the relationships between the constructs. As such, a Local theory can be developed about the constructs that emerged from the design principles. This Local theory can then serve as a meta-theory of the preconceptions on Lesson study.

The findings in this study indicate, that a Local theory can be developed to explain the constructs that emerge from design principles. The constructs then play a key role in the nature of the design principles and their presence suggests that the design principles and Local theory are interrelated. Also, it seems possible that a Local theory can be developed to explore, test and refine the role existing constructs play in design principles. Liden (2011) suggested that the theory-practice relationship must be revisited in empirical research since the interpretation of the findings depends on theory and implicates theory. Several aspects of design principles and Local theory require further investigation. These aspects include: understanding the nature of the relationship between metacognitive skills, language and networking. The design principles produced an understanding of the constructs and preconceptions of Lesson study which include metacognitive skills, language and networking. Because of its output, it is suggested that facilitators who wish to promote these skills in their classroom can consider meaningful activities that include collaborative and problem-based learning as teaching approaches.

\section{THE VALUE OF DESIGN PRINCIPLES AND LOCAL THEORY IN THE FACILITATION OF LESSON STUDY}

The purpose of design principles is to serve as instructional guidelines that address the issues emerging from practice. In contrast, the purpose of a Local theory is to explain and understand the nature of these design principles and their association to the constructs in a particular local setting. According to Craddock et al. (2013), this reinforces professional development and suggests a relationship between Lesson study's theory and practice. As an argument to include both design principles and Local theory in the facilitation of Lesson study, Bernath and Vidal (2007) suggested that improving educational quality takes place when researcher (e.g. facilitators and teachers concerned with theory and practice) bring forward new ideas and strategies to progress not only the teaching experience at the present but also to predict the quality of the learning experiences in the future. To accomplish this in the current study, the local route of Lesson study with its hypothesised learning trajectory is 
aligned against the design of design principles. The design principles' theoretical structure contextualises the teaching and learning environment and describes, interprets, explains and justifies the observations and reflections of the constructs that emerge when applying the design principles. The design principles then transform the practical issues (such as: What skills are necessary? How can these skills best be communicated? How are these skills connected?) into research problems that can be studied in terms of mini-pedagogical experiences or research lessons (Cobb et al., 2013). Then the design principles do not only provide guidelines for the educational experience, but also play a role in the rationale of the theoretical constructs that emerge from the Lesson study stages which, in turn, inform the Local theory, or way of teaching. When Lesson study is done, new ideas regarding best practices and effective teaching can develop through observations of, and reflections on the teaching and learning experience. The experiences can then be researched to determine how the emerging the underlying constructs of Lesson study informs design principles and Local theory. To do so, the constructs have to be explored, examined and understood as parameters or archetypes of the design principles and their relationship has to be explained through the Local theory, this will inform the development and refinement of Local theory.

It is then worth noting that the design principles have transformative potential for the teaching and learning field and, through Lesson study practice, this can lead to new ideas or theory. This impacts on the curriculum transformation processes, curriculum design and the inclusion of metacognition as a valuable component in Lesson study practice. This, however, remains in theory and need to be tested out in a variety of fields with the assistance of Lesson study's stages. Only then can the theory be revised, refined and adapted to suit the teaching and learning needs of the teacher, based on their particular Lesson study setup.

\section{CONCLUSION AND FUTURE DIRECTIONS}

When facilitating Lesson study, constructs can emerge that can inform design principles to improve practice and this can be used to inform the development and refinement of theory. The preconceptions outlined above explain that Lesson study can be facilitated with the underpinning assumptions of metacognitive skills, metacognitive language and metacognitive networking. As these constructs emerge from students' depictions of Lesson study, they can align with the design principles identified in Table 1 to refine the principles for future lessons. In doing so, these design principles can be employed to inform future Lesson study experiences and can therefore enhance Lesson study practice and theory. In conclusion, students who work collaboratively in Lesson study can preconceive the Lesson study theory from practice and, in the process, reflect on their own depictions of Lesson study with the emerging preconceptions built into the design principles. In the development of design principles and Local theory the constructs that underpin Lesson study, inform the development and refinement of theory by scrutinising the preconceptions that the theory holds to refine the theory accordingly.

\section{REFERENCES}

Baber, M. A. L. (2017). Exploring mathematical capital: An essential construct for mathematical success? (Doctoral dissertation), Portland State University.

Bernath, U., \& Vidal, M. (2007). The theories and the theorists: Why theory is important for research? Distances et savoirs, 5(3), 427-458.

Bustang, B., Zulkardi, Z., Darmawijoyo, H., Dolk, M., \& van Eerde, D. (2013). Developing a local instruction theory for learning the concept of angle through visual field activities and spatial representations. International Education Studies, 6(8), 58-70.

Cajkler, W., Wood, P., Norton, J., \& Pedder, D. (2013). Lesson study: Towards a collaborative approach to learning in initial teacher education. Cambridge Journal of Education, 1-19. https:/ / doi.org/10.1080/0305764X.2013.834037

Chval, K. B., Pinnow, R. J., \& Thomas, A. (2015). Learning how to focus on language while teaching mathematics to English language learners: a case study of Courtney. Mathematics Education Research Journal, 27(1), 103127. https:// doi.org/10.1007/s13394-013-0101-8

Cobb, P., Jackson, K., Smith, T., Sorum, M., \& Henrick, E. (2013). Design research with educational systems: Investigations and supporting improvements in the quality of mathematics teaching and learning at scale. National Society for the Study of Education, 112(2), 320-349.

Craddock, D., O'Halloran, C., McPherson, K., Hean, S., \& Hammick, M. (2013). A top-down approach impedes the use of theory? Interprofessional educational leaders' approaches to curriculum development and the use of learning theory. Journal of Interprofessional Care, 27, 65-72. https:/ / doi.org/10.3109/13561820.2012.736888

Curtin, M., \& Fossey, E. (2007). Appraising the trustworthiness of qualitative studies: Guidelines for occupational therapists. Australian Occupational Therapy Journal, 54, 88-94. https://doi.org/10.1111/j.14401630.2007.00661.x 
Ducasse, S., Denker, M., \& Lienhard, A. (2009, August). Evolving a reflective language: Lessons learned from implementing traits. In Proceedings of the International Workshop on Smalltalk Technologies (pp. 82-86). ACM. https://doi.org/10.1145/1735935.1735949

Elliott, R., Fischer, C. T., \& Rennie, D. L. (1999). Evolving guidelines for publication of qualitative research studies in psychology and related fields. British Journal of Clinical Psychology, 38, $215-229$. https:/ / doi.org/10.1348/014466599162782

Farrell, T. S. (2015). Reflective language teaching: From research to practice. Bloomsbury Publishing.

Flavell, J. H. (1979). Metacognition and cognitive monitoring: A new area of cognitive-developmental inquiry. American Psychologist, 34(10), 906-911. https:/ / doi.org/10.1037/0003-066X.34.10.906

Frith, C. D. (2012). The role of metacognition in human social interactions. Philosophical Transactions of the Royal Society, 367, 2213-2223. https://doi.org/10.1098/rstb.2012.0123

Graham, A., \& Phelps, R. (2003). 'Being a teacher': Developing teacher identity and enhancing practice through metacognitive and reflective learning processes. Australian Journal of Teacher Education, 27(2), 11-24. https:/ / doi.org/10.14221/ajte.2002v27n2.2

Gravemeijer, K. (2004). Local instruction theories as means of support for teachers in reform mathematics education. Mathematics Thinking and Learning, 6(2), 105-128. https://doi.org/10.1207/s15327833mt10602_3

Iiskala, T., Volet, S., Lehtinen, E., \& Vauras, M. (2015). Socially shared metacognitive regulation in asynchronous CSCL in science: Functions, evolution and participation. Frontline Learning Research, 3(1), 78-111.

Jagals, D. (2015). Metacognitive locale: a design-based theory of students' metacognitive language and networking in mathematics (Unpublished Doctoral thesis).

Jagals, D., \& Van der Walt, M. S. (2016). Exploiting metacognitive networks embedded in narrative focus group interviews using NodeXL. The Qualitative Report, 21(10), 1868-1880. Retrieved from https://nsuworks.nova.edu/tqr/vol21/iss10/8

Larsen, S., \& Lockwood, E. (2013). A local instructional theory for the guided reinvention of the quotient group concept. The Journal of Mathematical Behaviour, 32, 1-17. https:/ / doi.org/10.1016/j.jmathb.2013.02.010

Lidén, G. (2013). What about theory? The consequences on a widened perspective of social theory. Quality $\mathcal{E}$ Quantity, 47(1), 213-225. https:// doi.org/10.1007/s11135-011-9512-3

Lingard, B. (2015). Thinking about theory in educational research: Fieldwork in philosophy. Educational Philosophy and Theory, 47(2), 173-191. https:// doi.org/10.1080/00131857.2013.793928

Mevarech, Z., \& Kramarski, B. (2014). Critical maths for innovative societies: The role of metacognitive pedagogies. Paris: OECD. https:/ / doi.org/10.1787/9789264223561-en

Nachlieli, T., \& Tabach, M. (2012). Growing mathematical objects in the classroom - the case of function. International Journal of Educational Research, 51, 10-27. https:/ / doi.org/10.1016/j.ijer.2011.12.007

Nickerson, S. D., \& Whitacre, I. (2013). A local instruction theory for the development of number sense. Mathematics Thinking and Learning, 12, 227-252. https:/ / doi.org/10.1080/10986061003689618

Papaleontiou-Louca, E. (2008). Metacognition and theory of mind. Newcastle, UK: Cambridge Scholars Publishing.

Pasquali, A., Timmermans, B., \& Cleeremans, A. (2010). Know thyself: metacognitive networks and measures of consciousness. Cognition, 117(2), 182-190. https:/ / doi.org/10.1016/j.cognition.2010.08.010

Saldaña, J. (2015). The coding manual for qualitative researchers. Sage.

Schoenfeld, A. H. (2016). Learning to think mathematically: Problem solving, metacognition, and sense making in mathematics (Reprint). Journal of Education, 196(2), 1-38. https:/ / doi.org/10.1177/002205741619600202

Schraw, G., \& Moshman, D. (1995). Metacognitive theories. Educational psychology review, 7(4), 351--371. https:/ / doi.org/10.1007/BF02212307

Sriraman, B., \& English, L. (2010). Theories of mathematics education. New York: Springer. https:// doi.org/10.1007/978-3-642-00742-2

Wilkerson, J. B. (2017). Cultivating mathematical affections: developing a productive disposition through engagement in service-learning (Doctoral dissertation).

Woodruff, S., Cox, C., Tosa, S., \& Farrell, A. (2013). Lesson study mathematics professional development in an urban elementary school: Sustaining a promising practice. Columbus: Ohio Education Research Centre.

\section{http://www.ejmste.com}

